\title{
Telocytes in the mouse testicular interstitium: implications of G-protein-coupled estrogen receptor (GPER) and estrogen-related receptor (ERR) in the regulation of mouse testicular interstitial cells
}

\author{
Piotr Pawlicki ${ }^{1}$ - Anna Hejmej ${ }^{1}$ - Agnieszka Milon ${ }^{1} \cdot \mathrm{Krzysztof} \mathrm{Lustofin}^{1} \cdot$ Bartosz J. Płachno $^{2}$ - Waclaw Tworzydlo ${ }^{3}$. \\ Ewelina Gorowska-Wojtowicz $^{1} \cdot$ Bernadetta Pawlicka $^{4} \cdot$ Malgorzata Kotula-Balak $^{1} \cdot$ Barbara Bilinska $^{1}$
}

Received: 6 June 2018 / Accepted: 24 August 2018 / Published online: 5 September 2018

(C) The Author(s) 2018

\begin{abstract}
Telocytes (TCs), a novel type of interstitial cells, are involved in tissue homeostasis maintenance. This study aimed to investigate TC presence in the interstitium of mouse testis. Additionally, inactivation of the G-coupled membrane estrogen receptor (GPER) in the testis was performed to obtain insight into TC function, regulation, and interaction with other interstitial cells. Mice were injected with a GPER antagonist (G-15;50 $\mu \mathrm{g} / \mathrm{kg}$ bw), and the GPER-signaling effect on TC distribution, ultrastructure, and function, as well as the interstitial tissue interaction of GPER with estrogen-related receptors (ERRs), was examined. Microscopic observations of TC morphology were performed with the use of scanning and transmission electron microscopes. Telocyte functional markers (CD34; c-kit; platelet-derived growth factor receptors $\alpha$ and $\beta, \operatorname{PDGFR} \alpha$ and $\beta$; vascular endothelial growth factor, VEGF; and vimentin) were analyzed by immunohistochemistry/immunofluorescence and Western blot. mRNA expression of CD34 as well as ERR $\alpha, \beta$, and $\gamma$ was measured by qRT-PCR. Relaxin and $\mathrm{Ca}^{2+}$ concentrations were analyzed by immunoenzymatic and colorimetric assays, respectively. For the first time, we reveal the presence of TCs in the interstitium together with the peritubular area of mouse testis. Telocytes were characterized by specific features such as a small cell body and extremely long prolongations, constituting a three-dimensional network mainly around the interstitial cells. Expression of all TC protein markers was confirmed. Based on scanning electron microscopic observation in GPER-blocked testis, groups of TCs were frequently seen. No changes were found in TC ultrastructure in GPER-blocked testis when compared to the control. However, tendency to TC number change (increase) after the blockage was observed. Concomitantly, no changes in mRNA CD34 expression and increase in ERR expression were detected in GPER-blocked testes. In addition, $\mathrm{Ca}^{2+}$ was unchanged; however, an increase in relaxin concentration was observed. Telocytes are an important component of the mouse testicular interstitium, possibly taking part in maintaining its microenvironment as well as contractile and secretory functions (via themselves or via controlling of other interstitial cells). These cells should be considered a unique and useful target cell type for the prevention and treatment of testicular interstitial tissue disorders based on estrogen-signaling disturbances.
\end{abstract}

Keywords Cell biology $\cdot$ G estrogen receptor $\cdot$ Estrogen-related receptor $\cdot$ Mouse $\cdot$ Telocytes $\cdot$ Testis $\cdot$ Ultrastructure

Piotr Pawlicki and Anna Hejmej contributed equally to this work.

Handling Editor: Margit Pavelka

Malgorzata Kotula-Balak

malgorzata.kotula-balak@uj.edu.pl

1 Department of Endocrinology, Institute of Zoology and Biomedical Research, Jagiellonian University in Kraków, Gronostajowa 9, 30-387 Krakow, Poland

2 Department of Plant Cytology and Embryology, Institute of Botany, Jagiellonian University in Kraków, Gronostajowa 9, 30-387 Krakow, Poland
3 Department of Developmental Biology and Invertebrate Morphology, Institute of Zoology and Biomedical Research, Jagiellonian University in Kraków, Gronostajowa 9, 30-387 Krakow, Poland

4 Department of Genetics and Evolution, Institute of Zoology and Biomedical Research, Jagiellonian University in Kraków, Gronostajowa 9, 30-387 Krakow, Poland 


\section{Introduction}

Telocytes have been previously described by Popescu et al. (2005) in human pancreas, fallopian tube, and cardiac, digestive, and reproductive systems where they were named interstitial Cajal-like cells. Based on their extremely long prolongations (telopodes), telocytes (TCs) are easily distinguished from other interstitial tissue cells (Popescu and FaussonePellegrini 2010). Telopodes are hundreds of micrometers long and extremely thin (between 0.05 and $0.2 \mu \mathrm{m}$ ), making up a succession of thin, fibrillar segments (podomers) and dilated, cistern-like regions (podoms) (Cretoiu and Popescu 2014). Podoms accommodate functional units consisting of caveolae, mitochondria, and endoplasmic reticulum, possibly involved in calcium ion $\left(\mathrm{Ca}^{2+}\right)$ uptake and release (Cretoiu et al. 2012). These cells are interconnected by homo- and heterocellular junctions to form three-dimensional networks within the interstitial tissue (Cretoiu and Popescu 2014). In TC ultrastructure, large numbers of mitochondria, an abundance of endoplasmic reticulum and lipid droplets, and distinct sets of membrane channels are observed. Recent studies report the involvement of TCs in processes occurring at the cellular level: organizational regulation and activity of the extracellular matrix, structural support, formation of microenvironments, intercellular communication, neurotransmission, immunomodulation and immune surveillance, cell survival and apoptosis, and control of other cell types in the interstitium (Díaz-Flores et al. 2016). Telocytes are widely distributed in the interstitium of various organs as well as in serous membranes of vertebrates (fish, reptiles, birds, and mammals, including humans) (Popescu et al. 2010; Mostafa et al. 2010; Hinescu et al. 2011; Popescu 2011; Sanders et al. 2014; Yang et al. 2014).

In tissue pathology, variations in TC number have been demonstrated in both experimental and clinical studies. For example, in mice after hepatic resection, liver tissue regeneration was observed. Telocytes affected hepatocyte proliferation and/or hepatic stem cell differentiation via intercellular junctions and ectovesicles (Wang et al. 2014). Reduction in TC number, correlating with fibrosis, was noted in the gastrointestinal tract of patients with Crohn's disease (Milia et al. 2013). The loss of TCs was revealed in the aging heart, while in myocardial fibrotic areas of myocardial infarction and systemic sclerosis, TCs were almost completely absent, indicating their impaired function (Popescu et al. 2015). Alternatively, in cell fibrosis, TCs promoted cell hypertrophy as was demonstrated in exercise-induced cardiac cells (Xiao et al. 2016).

Minimal data is available on the localization and role of TCs in the male reproductive system. Mokhtar et al. (2016) revealed TCs in seminal vesicles of the Soay ram. In the prostate, the involvement of TCs in tissue organization during postnatal development has been demonstrated (Sanches et al. 2017). Telocytes were found in human testis, particularly in men with prostate cancer (based on c-kit immunostaining) and those with nonobstructive azoospermia (Rodríguez et al. 2008; Hasirci et al. 2017). The latter study confirmed that the number and distribution of TCs may affect spermatogenesis. The number of TCs was higher in patients with nonobstructive azoospermia than in those with obstructive azoospermia (Hasirci et al. 2017). Yang et al. (2015) reported the presence of TCs in the testis of the Chinese softshell turtle (Pelodiscus sinensis).

In the testis, the interstitium is located in between seminiferous tubules. This tissue is composed of loose connective tissue with blood and lymph vessels, macrophages, fibroblasts, mast cells, lymphocytes, and Leydig cells, which are the main component (Christensen 1975). The peritubular area, with a layer of smooth muscle cells (peritubular-myoid cells), directly delimits seminiferous tubules from the interstitium. Multiple and multilevel interactions of molecules secreted by testicular cells, or transported to the testis from other tissues, are responsible for maintaining the local microenvironment that is crucial for spermatogenic and steroidogenic functions (Skinner et al. 1991).

Estrogen signaling in the male reproductive system is important for proper fertility (Hess 2003). Responses to estrogens, both genomic and rapid signaling, are initiated by nuclear receptors: estrogen receptors (ERs), their splice-variants, membrane G-coupled estrogen receptor (GPER), and estrogen-related receptors (ERRs) (Bjornstrom and Sjoberg 2005; Vrtačnik et al. 2014). While ERRs show a high degree of DNA sequence homology to ERs, and function alongside the estrogen mechanism of action (Huppunen and Aarnisalo 2004), GPER has different biochemical and molecular characteristics. This seven-transmembrane domain receptor is associated with $\mathrm{G}$ proteins, thus playing a fundamental role in coupling external stimuli with cytoplasmic and nuclear targets after activation, and is dependent on cooperation with growth factor receptors (Vögler et al. 2008). Indeed, due to GPER localization, it is an initial sensor of exogenous estrogen action.

Currently, multiple groups have shown the expression of novel receptors: GPER and ERR in rodent Leydig cells both in vivo and in vitro (Chimento et al. 2014; Vaucher et al. 2014; Pardyak et al. 2016; Zarzycka et al. 2016; Park et al. 2017; Pawlicki et al. 2017). The interaction of GPER with intratesticular estrogen levels was reported in male bank voles with normal and physiologically decreased estrogen levels as well as in male mice of various ages (Zarzycka et al. 2016; Kotula-Balak et al. 2018). Also, ERR regulation via serum hormonal factors, as well as phytoestrogens and synthetic hormonally active compounds, was demonstrated in various tissues (Vanacker et al. 1999; Roshan-Moniri et al. 2014; Pardyak et al. 2016; Milon et al. 2017). Moreover, the implication of both GPER and ERR action 
in testicular steroidogenic cell function was shown (Vaucher et al. 2014; Park et al. 2017). Despite the fact that the role of lipid droplets in TCs is not recognized, their function was found to be controlled by $\mathrm{Ca}^{2+}$ signaling (Radu et al. 2017).

This study aimed to explore the presence of TCs in the mouse testicular interstitium. In addition, we focused on interstitium function as a result of GPER and ERR signaling as well as the possible involvement of TCs in maintaining proper interstitial cell histology and function.

\section{Materials and methods}

\section{Animals and treatments}

Male mice (C57BL/6), 3 months old $(n=10)$, were obtained from the Department of Genetics and Evolution, Institute of Zoology and Biomedical Research, Jagiellonian University, Kraków. Animals were maintained on $12 \mathrm{~h}$ dark-light (250 lx at cage level) cycle with stable temperature condition $\left(22{ }^{\circ} \mathrm{C}\right)$, relative humidity of $55 \pm 5 \%$, and free access to water and standard pelleted diet (LSM diet, Agropol, Motycz, Poland). Animals were killed by cervical dislocation. The use of the animals was approved by the National Commission of Bioethics at the Jagiellonian University in Krakow, Poland (No. 151/2015).

Mice were allotted into experimental groups (each group including five animals) and control (Cont.) and treated with a selective GPER receptor antagonist $\left[\left(3 \mathrm{a} S^{*}, 4 R^{*}, 9 \mathrm{~b} R^{*}\right)\right.$ 4-(6-bromo-1,3-benzodioxol-5-yl)-3a, 4,5,9b-3 Hcyclopenta[c]quinolone; G-15] (Tocris Bioscience, Bristol, UK). G-15 was dissolved in DMSO and the stock solutions were kept at $-20{ }^{\circ} \mathrm{C}$. Animals from the experimental groups were injected subcutaneously with freshly prepared solutions of G-15 (50 $\mu \mathrm{g} / \mathrm{kg}$ bw) in phosphate-buffered saline (six doses each dose injected every other day). Mice from control groups received vehicle only. Dose, frequency, and time of G-15 administration were based on our previous study (Kotula-Balak et al. 2018). Both testes of each individual of control and G-15-treated mice were surgically removed and were cut into small fragments. For histological appearance and immunohistochemistry, tissue samples were fixed in $10 \%$ formalin and embedded in paraplast, or small pieces of the testicular tissue were immediately fixed in formaldehyde and glutaraldehyde (see "Materials and methods": "Cell topography_-scanning electron microscope (SEM)" and "Cell ultrastructure-transmission electron microscope (TEM)" sections, respectively) for transmission microscopy analysis or frozen in liquid nitrogen and stored at $-80{ }^{\circ} \mathrm{C}$ for RNA isolation and determination of steroid hormones.

\section{Cell topography—scanning electron microscope (SEM)}

Control and G-15-treated testes were fixed in a mixture of $2.5 \%$ formaldehyde with $2.5 \%$ glutaraldehyde in a $0.05-\mathrm{M}$ cacodylate buffer (Sigma; $\mathrm{pH}$ 7.2) for several days, washed three times in a $0.1-\mathrm{M}$ sodium cacodylate buffer, and later dehydrated and subjected to critical-point drying. They were then sputter-coated with gold and examined at an accelerating voltage of 20 or $10 \mathrm{kV}$ using a Hitachi S-4700 scanning electron microscope (Hitachi, Tokyo, Japan).

\section{Cell ultrastructure-transmission electron microscope (TEM)}

Control and G-15-treated fragments of testes were immersed in ice-cold prefixative containing $2 \%$ formaldehyde and $2.5 \%$ glutaraldehyde in $0.1 \mathrm{M}$ phosphate buffer, $\mathrm{pH} 7.3$ overnight at $4{ }^{\circ} \mathrm{C}$. The tissues were then rinsed and postfixed in a mixture of $2 \%$ osmium tetroxide and $0.8 \%$ potassium ferrocyanide in the same buffer for $30 \mathrm{~min}$ at $4{ }^{\circ} \mathrm{C}$ (Russell and Burguet 1977; McDonald 1984). The material was embedded in Glycid Ether 100 resin (Serva, Heidelberg, Germany). Semithin sections $(0.7 \mu \mathrm{m}$ thick) were stained with $1 \%$ methylene blue and examined under a Leica DMR (Wetzlar, Germany) microscope. Prior to embedding, small (3-5 mm) pieces of testicular tissue were carefully oriented in the mold to obtain accurate cross sections of the interstitial tissues and tubules. Ultrathin sections ( $80 \mathrm{~nm}$ thick) were contrasted with uranyl acetate and lead citrate and analyzed with a JEOL 2100 HT (Japan) TEM.

\section{RNA isolation and reverse transcription}

Total RNA was extracted from control and G-15-treated mouse testes using TRIzol ${ }^{\circledR}$ reagent (Life Technologies, Gaithersburg, MD, USA) according to the manufacturer's instructions. The yield and quality of the RNA were assessed using a NanoDrop ND2000 Spectrophotometer (Thermo Scientific, Wilmington, DE, USA). Samples with a $260 / 280$ ratio of 1.95 or greater and a $260 / 230$ ratio of 2.0 or greater were used for analysis. Total cDNA was prepared using HighCapacity cDNA Reverse Transcription Kit (Applied Biosystems, Carlsbad, CA, USA) according to the manufacturer's instructions.

The purified total RNA was used to generate total cDNA. A volume equivalent to $1 \mu \mathrm{g}$ of total RNA was reverse transcribed using the High-Capacity cDNA Reverse Transcription Kit (Applied Biosystems, Carlsbad, CA, USA) according to the manufacturer's instructions. Total cDNA was prepared in a $20-\mu \mathrm{L}$ volume using a random primer, dNTP mix, RNase inhibitor, and reverse transcriptase (RT). Parallel reactions for each RNA sample were run in the absence of RT to assess 
genomic DNA contamination. RNase-free water was added in place of the RT product.

\section{Real-time quantitative RT-PCR}

Real-time RT-PCR was performed using the StepOne RealTime PCR system (Applied Biosystems) and optimized standard conditions as described previously by Kotula-Balak et al. (2013, 2018). Based on the gene sequences in Ensembl database, primer sets were designed using Primer3 software (Table 1). Selected primers were synthesized by the Institute of Biochemistry and Biophysics, Polish Academy of Sciences (Warsaw, Poland).

To calculate the amplification efficiency, serial cDNA dilution curves were produced for all genes (Pfaffl 2001). A graph of threshold cycle $(\mathrm{Ct})$ versus $\log 10$ relative copy number of the sample from a dilution series was produced. The slope of the curve was used to determine the amplification efficiency: $\% \mathrm{E}=\left(10^{-1 / \text { slope }}-1\right) \times 100$. All PCR assays displayed efficiency between 94 and 104\%.

Detection of amplification products for CD34, ERR $\alpha$, $\mathrm{ERR} \beta$, and $\mathrm{ERR} \gamma$, and for the reference gene $\beta$-actin, was performed with $10 \mathrm{ng}$ cDNA, $0.5 \mu \mathrm{M}$ primers, and SYBR Green master mix (Applied Biosystems) in a final volume of $20 \mu \mathrm{L}$. Amplifications were performed as follows: $55^{\circ} \mathrm{C}$ for $2 \mathrm{~min}, 94^{\circ} \mathrm{C}$ for $10 \mathrm{~min}$, followed by annealing temperature for $30 \mathrm{~s}$ (Table 1) and $45 \mathrm{~s} 72{ }^{\circ} \mathrm{C}$ to determine the cycle threshold $(\mathrm{Ct})$ for quantitative measurement as described previously (Kotula-Balak et al. 2013). To confirm amplification specificity, the PCR products from each primer pair were subjected to melting curve analysis and subsequent agarose gel electrophoresis (not shown). In all real-time RT-PCR reactions, a negative control corresponding to RT reaction without the reverse transcriptase enzyme and a blank sample were carried out. All PCR products stained with Midori Green Stain (Nippon Genetics Europe GmbH, Düren, Germany) were run on agarose gels. Images were captured using a BioRad Gel Doc XR System (Bio-Rad Laboratories, Hercules, CA, USA) (not shown). CD34, ERR $\alpha, E R R \beta$, and ERR $\gamma$ mRNA expressions were normalized to the $\beta$-actin mRNA (tested with other references genes: GAPDH and Tuba1 $\alpha$ in a pilot study) (relative quantification, $R Q=1$ ) with the use of the $2^{-\Delta \Delta \mathrm{Ct}}$ method, as previously described by Livak and Schmittgen (2001).

Three independent experiments were performed, each in triplicate with tissues prepared from different animals.

\section{Western blot}

Lysates of testes (of the control and GPER-blocked) were obtained by sample homogenization and sonication with a cold Tris/EDTA buffer (50 mM Tris, 1 mM EDTA, pH 7.5), supplemented with broad-spectrum protease inhibitors
(Sigma-Aldrich). The protein concentration was estimated by the Bio-Rad DC Protein Assay Kit with BSA as standard (Bio-Rad Labs, GmbH, München, Germany). Equal amounts of protein were resolved by SDS-PAGE under reducing conditions, transferred to polyvinylidene difluoride membranes (Merck Millipore, Darmstadt, Germany), and analyzed by Western blotting with antibodies listed in Table 2. The presence of the primary antibody was revealed with horseradish peroxidase-conjugated secondary antibodies diluted 1:3000 (Vector Lab., Burlingame, CA, USA) and visualized with an enhanced chemiluminescence detection system as previously described (Zarzycka et al. 2016). All immunoblots were stripped with stripping buffer containing $62.5 \mathrm{mM}$ Tris- $\mathrm{HCl}$, $100 \mathrm{mM}$ 2-mercaptoethanol, and $2 \% \operatorname{SDS}(w / v ; \mathrm{pH} 6.7)$ at $50{ }^{\circ} \mathrm{C}$ for $30 \mathrm{~min}$ and incubated in antibody against $\beta$-actin (loading control). Three independent experiments were performed, each in triplicate with tissues prepared from different animals. To obtain quantitative results, the bands (representing each data point) were densitometrically scanned using the public domain ImageJ software (National Institutes of Health, Bethesda, MD, USA) (Smolen 1990). The data obtained for each protein were normalized against its corresponding actin and expressed as relative intensity. Results of 10 separate measurements were expressed as mean $\pm \mathrm{SD}$.

\section{Immunohistochemistry and immunofluorescence}

To optimize immunohistochemical staining testicular sections (4 $\mu \mathrm{m}$ thin), both control and G-15-treated mice were immersed in $10 \mathrm{mM}$ citrate buffer $(\mathrm{pH} \mathrm{6.0)}$ and heated in a microwave oven $(2 \times 5 \mathrm{~min}, 700 \mathrm{~W})$. Thereafter, sections were immersed sequentially in $\mathrm{H}_{2} \mathrm{O}_{2}(3 \% ; v / v)$ for 10 min and normal goat or horse serum $(5 \% ; v / v)$ for $30 \mathrm{~min}$ which were used as blocking solutions. After overnight incubation at $4{ }^{\circ} \mathrm{C}$ with primary antibodies listed in Table 2 , the next respective biotinylated antibodies (anti-rabbit, anti-goat, and anti-mouse IgGs; 1: 400; Vector, Burlingame CA, USA) and avidinbiotinylated horseradish peroxidase complex (ABC/HRP; 1:100; Dako, Glostrup, Denmark) were applied in succession. Bound antibody was visualized with 3,3'-diaminobenzidine (DAB) $(0.05 \%$; v/v; Sigma-Aldrich) as a chromogenic substrate. Control sections included omission of primary antibody and substitution by irrelevant IgG. Thereafter, sections were washed and were slightly counterstained with Mayer's hematoxylin and mounted using DPX mounting media (SigmaAldrich).

To count TC number per testicular section, the volume of CD34-positive cells per section was determined by a pointcounting method using a graticule with 121 points (according to Sharpe et al. 2000 with modifications). Serial testicular sections (three to five) from each of the animals (control and G-15-treated mice) were examined. Applying a systematic sampling pattern from a random starting point, approx. 60 
Table 1 Sequences of forward and reverse primers

\begin{tabular}{|c|c|c|c|c|}
\hline Genes & Primers $\left(5^{\prime}-3^{\prime}\right)$ & Product size (bp) & Annealing temperature $\left({ }^{\circ} \mathrm{C}\right)$ & Cycles \\
\hline CD34 & $\begin{array}{l}\text { 5'-TAGCTCTCTGCCTGATGAGTCTGCTG-3' } \\
\text { 5'-CTGAGATGGCTGGTGTGGTCTTACTG-3' }\end{array}$ & 234 & 61.1 & 40 \\
\hline $\mathrm{ERR} \alpha$ & $\begin{array}{l}\text { 5'-GCCTCTACCCAAACCTCTCT-3' } \\
\text { 5'-AGCCAT CCCTCCTTCGCACA-3' }\end{array}$ & 234 & 60 & 40 \\
\hline $\mathrm{ERR} \beta$ & $\begin{array}{l}\text { 5'-GAGCCATCTTTACCGCTGGA-3' } \\
\text { 5'-CAGCTTGTCAACAGGCAGTG-3' }\end{array}$ & 239 & 60 & 40 \\
\hline $\mathrm{ERR} \gamma$ & $\begin{array}{l}\text { 5'-CTTGTAATGGGGTTGCCTC-3' } \\
\text { 5'-TATCACCTTCTGCCGACCT-3' }\end{array}$ & 222 & 62 & 40 \\
\hline$\beta$-Actin & $\begin{array}{l}\text { 5'-AAGTACCCCATTGAACACGG-3' } \\
\text { 5'-ATCACAATGCCAGTGGTACG-3' }\end{array}$ & 274 & 52 & 40 \\
\hline
\end{tabular}

$E R R \alpha$, estrogen-related receptor alpha; $E R R \beta$, estrogen-related receptor beta; $E R R \gamma$, estrogen-related receptor gamma

fields were counted. Results were expressed as mean number per testicular section.

Fluorescence labeling for F-actin was performed on testicular sections fixed in absolute methanol for $7 \mathrm{~min}$ followed by acetone for 4 min both at $-20^{\circ} \mathrm{C}$, respectively. Next, sections were rinsed in TBS containing $0.1 \%$ Triton $\mathrm{X}-100$. Thereafter, cells were incubated with rhodamine-conjugated phalloidin (cat. no. R415, Invitrogen Molecular Probes) that recognizes F-actin for $30 \mathrm{~min}$ in a dark chamber for $30 \mathrm{~min}$ in a humidified chamber. After this step, cells were carefully rinsed with TBS. Fluorescent staining was protected from light and cells were mounted with Vectashield mounting medium (Vector Labs) with 4',6-diamidino-2-phenylindole (DAPI) and next examined with epifluorescence microscope Leica DMR (Leica Microsystems) equipped with appropriate filters. Experiments were repeated three times.

Counting of F-actin-positive cells was performed on 10 randomly chosen microscopic high-power fields (hpf; $\times 40)$

Table 2 Primary antibodies used for immunohistochemistry and Western blotting

\begin{tabular}{llll}
\hline Antibody & Host species & Vendor & Dilution \\
\hline CD34 & \multirow{2}{*}{ Rabbit } & Abcam & $1: 200$ (IHC) \\
& & Cat. no. ab81289 & $1: 500$ (WB) \\
c-kit & \multirow{2}{*}{ Rabbit } & Thermo Fisher & $1: 1000$ (IHC) \\
& & Cat. no. \#34-8800 & $1: 500(\mathrm{WB})$ \\
PDGFR $\alpha$ & \multirow{2}{*}{ Rabbit } & Cell Signaling Technology & $1: 500(\mathrm{IHC})$ \\
& & Cat. no. \#3174 & $1: 500(\mathrm{WB})$ \\
PDGFR $\beta$ & \multirow{2}{*}{ Mouse } & Abcam & $1: 300(\mathrm{IHC})$ \\
& & Cat. no. ab69506 & $1: 500(\mathrm{WB})$ \\
VEGF & \multirow{2}{*}{ Rabbit } & Merck & $1: 300(\mathrm{IHC})$ \\
& & Cat. no. \#07-1420 & $1: 500(\mathrm{WB})$ \\
Vimentin & \multirow{2}{*}{ Rabbit } & Cell Signaling Technology & $1: 200(\mathrm{IHC})$ \\
& & Cat. no. \#5741 & $1: 500(\mathrm{WB})$ \\
$\beta$-Actin & \multirow{2}{*}{ Mouse } & Sigma-Aldrich & $1: 3000(\mathrm{WB})$ \\
& & Cat. no. A2228 & \\
\hline
\end{tabular}

c-kit, tyrosine-protein kinase kit, $P D G F R \alpha$, platelet-derived growth factor receptor $\alpha ; P D G F R \beta$, platelet-derived growth factor receptor $\beta ; V E G F$, vascular endothelial growth factor of the testicular sections according to Manetti et al. (2013). Total fluorescence (a.u.) of F-actin was measured with the use of ImageJ software (NIH, Bethesda, USA) according to Smolen (1990). Briefly, to calculate total fluorescence per region, mean values for interstitial tissue areas in serial sections were averaged including the background reading with the use of NIS-Elements software and expressed as total fluorescence (a.u).

\section{Relaxin concentration}

Relaxin concentration was measured in $(100 \mu \mathrm{L})$ lysates of control and G-15-treated testes with the use of mouse relaxin 1 ELISA Kit (cat. no. ab213885; Abcam) according to the manufacturer's protocol. The biological sensitivity of an assay was $<10 \mathrm{pg} / \mathrm{mL}$. For determination of optical density, a spectrophotometer (Labtech LT-4000MS; Labtech International Ltd., Uckfield, UK) with Manta PC analysis software set to $450 \mathrm{~nm}$ was used.

Concentrations of relaxin in G-15-treated testes were compared with the control. Relaxin concentration was calculated as picograms per milliliter.

\section{Determination of $\mathrm{Ca}^{2+}$ concentrations}

Control and G-15 testes homogenates were sonicated for $60 \mathrm{~s}$ on ice and centrifuged at $10,000 \mathrm{~g}$ for $15 \mathrm{~min} . \mathrm{Ca}^{2+}$ was estimated using Arsenazo III (Sigma-Aldrich, St. Louis, MO, USA) according to the modified method by Michaylova and Ilkova (1971). The intensity of the purple complex formed with the reagent was read at $600 \mathrm{~nm}$ in a spectrophotometer (Labtech LT-4000MS; Labtech International Ltd., Uckfield, UK) with Manta PC analysis software. The proteins were estimated by the modified Lowry's method (Lowry et al. 1951). Concentrations of $\mathrm{Ca}^{2+}$ in G-15-treated testes were compared with the control. The $\mathrm{Ca}^{2+}$ concentrations were calculated as micrograms per milliliter. 


\section{Statistical analysis}

Each variable was tested by using the Shapiro-Wilk $W$ test for normality. Homogeneity of variance was assessed with Levene's test. Since the distribution of the variables was nor$\mathrm{mal}$ and the values were homogeneous in variance, all statistical analyses were performed using one-way analysis of variance (ANOVA) followed by Tukey's post hoc comparison test to determine which values differed significantly from controls. The analysis was made using Statistica software (StatSoft, Tulsa, OK, USA). Data were presented as mean \pm SD. Data were considered statistically significant at $p<0.05$. All the experimental measurements were performed in triplicate.

\section{Results}

\section{Presence of telocytes in mouse testis-SEM, TEM, and immunohistochemical and fluorescence analyses: effect of GPER blockage}

In the testicular tissue, SEM analysis was utilized for observation of general interstitial cell topography. Only testis fragments with highly visible and untouched seminiferous tubules were used for analysis (Fig. 1a). The results revealed the presence of TCs in the testis interstitium between seminiferous tubules (Fig. 1b-f). In the control and GPER-blocked testes, TCs were present in both interstitial and peritubular areas and recognized by pale, small round body and very long, thin cellular prolongations (Fig. 1b-f and insert at b). Telocytes were located in close proximity to Leydig cells. The latter cells were recognized by a large polygonal body and short, wide pseudopodia located in groups where single cells tightly adhered to each other (Fig. 1b-e). In addition, TCs were present in between and/or on peritubular cells surrounding the seminiferous tubule's basement membrane (Fig. 1f). Telocytes were found to be spatially distributed and composed a netlike structure enclosing the interstitial space containing Leydig cells (Fig. 1b-f). On the body surface of TC body, little to no very short and thin cell processes were observed (Fig. 1d). The density of TCs was different by region, and they appeared either singularly or in small groups. More frequently, groups of TCs were observed in the interstitium of GPERblocked testes when compared to the control (Fig. 1b-d).

Concomitantly, TCs in the control and GPER-blocked testes were analyzed by TEM (Fig. 2). Analyses of serial sections revealed the presence of TCs in both peritubular and interstitial testis compartments (Fig. 2). TCs of both localizations had a similar appearance with a relatively small, rounded cell body and extremely elongated, thin pseudopodia. Nearly the entire cell body was filled with a slightly elongated nucleus surrounded by a small rim of cytoplasm. Well-developed elements of rough endoplasmic reticulum and numerous elongated and branched mitochondria were also observed (Fig. 2a, $\mathrm{b}, \mathrm{f}, \mathrm{g})$.

The most characteristic feature of the TCs was very long and thin cell protrusions (telopodes) that formed podom-like dilated structures (Fig. 2b, d). Occasionally, the single TC sent several elongated protrusions (Fig. 2b), but most TCs possessed a few remarkably long telopodes. The telopode cytoplasm contained mitochondria that were linearly arranged one by one (Fig. 2h). In the cortical regions of the telopode, numerous tightly packed filamentous structures were present (Fig. 2h, asterisk). Based on their structure and size, we believe the filaments represent F-actin microfilaments (Fig. 2h). In TCs surrounding the seminiferous tubule, the telopodes ran parallel to peritubular cells (Fig. 2a). In TCs that were located near Leydig cells, the long telopodes embraced Leydig cells and could be seen penetrating between adjacent Leydig cells (Fig. 2c). No characteristic changes in the ultrastructure of TCs were observed between the control and GPER-blocked testes.

Light microscopic observations were undertaken as an attempt for the identification and confirmation of TC location based on immunohistochemical staining for CD34 as well as c-kit, PDGFR $\alpha$, PDGFR $\beta$, VEGF, vimentin, and F-actin (Figs. 3, 4, and 5). Telocytes were located in between peritubular cells and surrounded groups of Leydig cells (Figs. 3 and 4). Moreover, single TCs positive for CD34 were identified between pericytes of blood vessels (Fig. 3c, d). Of note, no staining for CD34 was seen in other types of testicular cells, pericytes and peritubular cells, Leydig cells, and cells of the seminiferous tubules (Fig. 3). For PDGFR $\alpha, \operatorname{PDGF} \beta$, and VEGF, positive staining was not seen in Leydig cells and cells of seminiferous tubules (Fig. $4 \mathrm{c}-\mathrm{h}$ ). On the contrary, staining for c-kit and vimentin revealed that not only TCs express these proteins but also spermatogenic cells (positive for c-kit) and Sertoli cells and peritubular cells (positive for vimentin) (Fig. 4a, b and i, j). Moreover, nonspecific staining for c-kit was detected in Leydig cells as well. Telocytes were observed in both control and GPER-blocked testes, but as the other types of testicular cells expressed c-kit, PDGFR $\alpha$, PDGFR $\beta$, VEGF, and vimentin, only CD34-positive cells were used for further analyses.

Telocytes that positively stained for CD34 were observed in both control and GPER-blocked mouse testes. In control testis, the number of TCs positive for CD34 was 9.4 \pm 1.7 cells/testicular section, while it increased $\left(19.1 \pm 0.4^{* *}\right.$ cells/ testicular section) in GPER-blocked samples.

No staining was found in testicular sections incubated without primary antibody (inserts at Figs. $3 b$ and $4 a, d, e, h, j$ ).

Long telopodes that stained strongly for F-actin were revealed in both control and GPER-blocked testis. Telopodes were lying in between peritubular cells and surrounded the interstitial space and blood vessels (Fig. 5). Discontinuous 

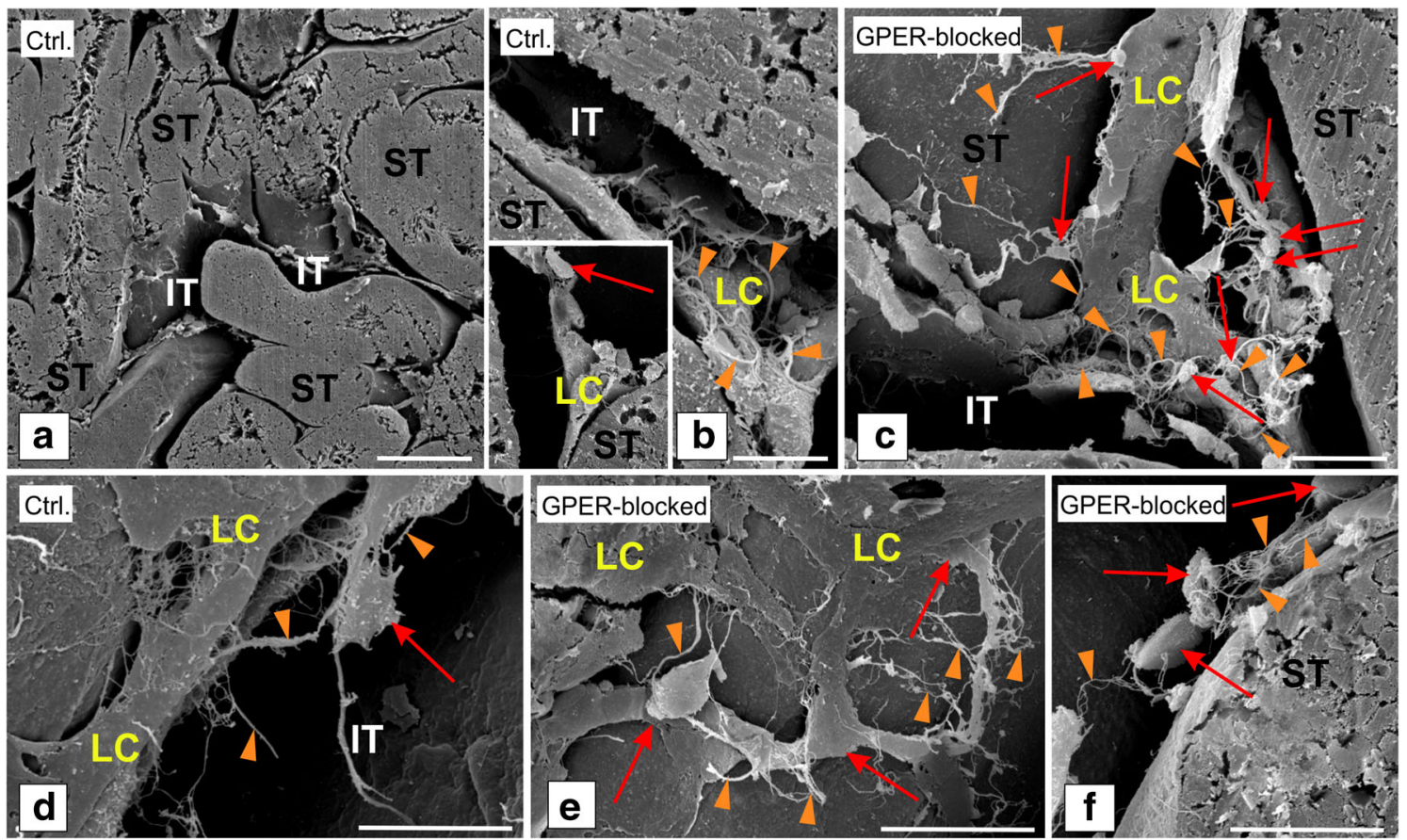

Fig. 1 Presence of telocytes in mouse testis - SEM analysis. Effect of GPER blockage. Representative microphotographs of sections of control $(\mathbf{a}, \mathbf{b}$ and insert, $\mathbf{d})$ and GPER-blocked (c, e, and f) coated with gold. Bars represent $1 \mu \mathrm{m}$. Analysis was performed on three testicular fragments

from at least three animals of each experimental group. TCs are marked with red arrows, while their long and thin protrusions (telopodes) with orange arrowheads. Note increased number of TCs in GPER-blocked testes. IT, interstitial tissue; ST, seminiferous tubules; LC, Leydig cells

strong signal for F-actin (indicated on the presence of other cell types, e.g., peritubular-myoid in the peritubular area, pericytes in blood vessel epithelium and Leydig cells, fibroblast in the interstitium) when compared to DAPI staining was detected in the area outside seminiferous tubules. The relative fluorescence of F-actin was increased $(p<0.01)$ in comparison to controls (Fig. 5E).

\section{Expression of CD34, c-kit, PDGFRa, PDGFR $\beta$, VEGF, and vimentin in mouse testis: effect of GPER blockage}

Changes in the level of telocyte marker proteins CD34, c-kit, PDGFR $\alpha$, PDGFR $\beta$, VEGF, and vimentin were found in G15 testis when compared to the control (Fig. 6a, b). The protein level of CD34 was increased $(p<0.05)$ in GPER-blocked testis. The expression of c-kit was found to be increased $(p<0.01)$ too, while PDGFR $\alpha$, PDGFR $\beta$, VEGF, and vimentin expression decreased in GPER-blocked testis $(p<0.01 ; p<0.05)$. Expression of VEGF was decreased but not significantly.

\section{Expression of CD34 and ERR mRNA in mouse testis: effect of GPER blockage}

No changes in CD34 mRNA levels were found in GPERblocked testis in comparison to controls (Fig. 7). Alternatively, the mRNA expression of ERR $\alpha, \beta$, and $\gamma$ markedly increased $(p<0.01 ; p<0.001)$.

\section{Intratesticular relaxin and $\mathrm{Ca}^{2+}$ concentrations: effect of GPER blockage}

A significant increase in relaxin concentration $(p<0.01)$ (Fig. 8a) and a slight increase in $\mathrm{Ca}^{2+}$ concentration (Fig. $8 b)$ were revealed in GPER-blocked testis when compared to the control.

\section{Discussion}

We report, for the first time, the presence of TCs in the interstitium, including the peritubular area, of mouse testis. Our results are in accord with the observations of Rodríguez et al. (2008) and Hasirci et al. (2017) on TC location in human testis. Telocytes reside in both peritubular and perivascular areas of the testis' interstitium regardless of species (Yang et al. 2015). These cells are universally considered "connecting cells," primarily involved in intercellular signaling. Telocytes have "strategic" positioning in a tissue, in between blood capillaries and their specific target cells (Popescu and Faussone-Pellegrini 2010) that in the testes can be especially cells outside seminiferous tubules. They are implicated in the electrical modulation of excitable tissue (the smooth muscle of the gut and uterus) and are capable of spontaneous initiation of electrical activity involving $\mathrm{Ca}^{2+}$ transients (Yamashita 2010). Moreover, TCs express ER $\alpha$ and the 
Fig. 2 Presence of telocytes in mouse testis - TEM analysis. Effect of GPER blockage. Representative microphotographs of ultrathin sections of TCs from control (a-d and $\mathbf{f}-\mathbf{h}$ ) and GPERblocked mouse testes (e). Bars represent $1 \mu \mathrm{m}$. Each testicular sample in epoxy resin block was cut for at least three ultrathin sections that were analyzed. Analysis was performed on testicular blocks from at least three animals of each experimental group. ST, seminiferous tubules; TC, telocyte; LC, Leydig cells; m, mitochondria, PC, peritubular cell; asterisk - cortical filaments; rer-elements of endoplasmic reticulum. Note long protrusions (telopodes) of the TCs (arrows). Sometimes the TCs send several protrusions toward one direction (yellow arrows in b). In some cases, the telopodes intertwine with one another and form characteristic labyrinths (yellow arrowheads in d). Note dilated fragments of the telopodes that form podomer-like structures (blue arrows in b). The TCs that are located in close vicinity to Leydig cells very often send protrusions that penetrate in-between adjacent Leydig cells (arrows in c)
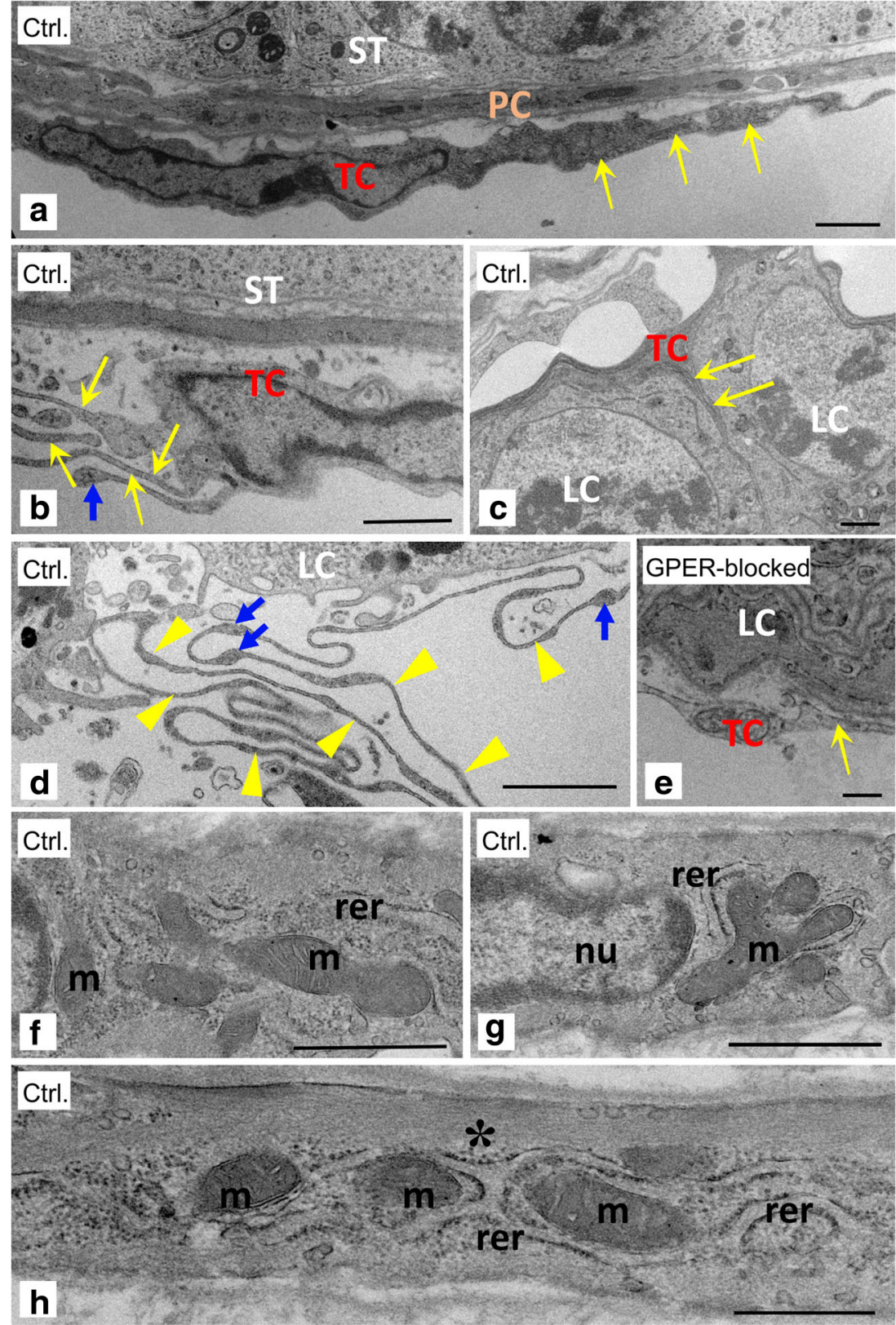

progesterone receptor, both of which are important hormone sensors (for review, see Roatesi et al. 2015).

When GPER was blocked in mouse testis, intratesticular estrogen levels, as well as estrogen feedback regulation of its own signaling, were altered (Kotula-Balak et al. 2018). Potential differences in the number of TCs of the control and GPER-blocked testes could exist as we revealed interstitial tissue-marked histological modulations for the first time. It is possible that TCs as well as other cells of the peritubular and interstitial compartments, peritubular-myoid cells, and Leydig cells may express GPER (Sandner et al. 2014; Zarzycka et al. 2016; Kotula-Balak et al. 2018). Therefore, changes in TC number may be a response to perturbed estrogen signaling and/or are a result of modulated function of neighboring cells as was reported in physiological and pathological conditions of various human organs (Cretoiu et al. 2012; Milia et al. 2013; Wang et al. 2014; Fu et al. 2015; Xiao et al. 2016).

As a first step, herein, general morphological characteristics of interstitial cells were assessed by SEM. Testis tissue is composed of two compartments made up of various cell types. Therefore, some limitations of SEM should be mentioned. Firstly, cutting testicular tissue requires precision and further processing needs to be gentle so as not to destroy the seminiferous tubules, as those cells can contaminate the interstitial space. Second, for analysis, only tissue which is spontaneously and exactly broken (during the procedure) in-between tubules allows for observation of the interstitial compartment. 


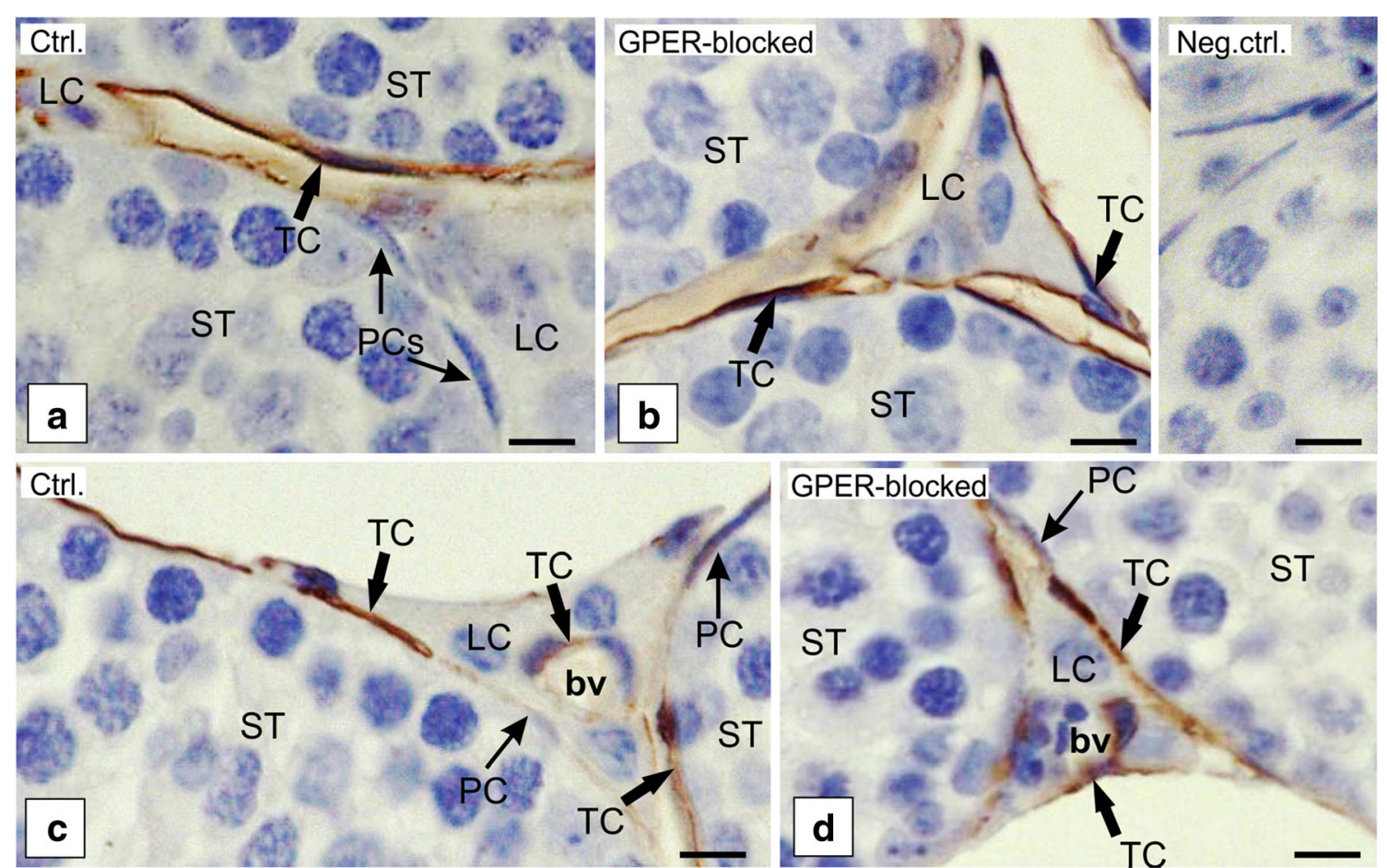

Fig. 3 Presence of telocytes in mouse testis - immunohistochemical analysis. Effect of GPER blockage. Representative microphotographs of CD34 immunohistochemical localization in control (a, c) and GPERblocked $(\mathbf{b}, \mathbf{d})$ mouse testes. Immunostaining with DAB and counterstaining with hematoxylin. Scale bars represent $15 \mu \mathrm{m}$.

Ultrastructural observations revealed that testicular TCs have remarkably long, thin, and moniliform, actin-rich cellular projections referred to as telopodes. Of note, for identification of telopodes of testicular TCs, F-actin seems to be an accurate and helpful marker, that clearly distinguishes F-actin-
Immunoreaction was performed on testicular serial sections from at least three animals of each experimental group. Insert at $\mathbf{b}$ - negative controls. bv, blood vessels; LC, Leydig cells; PC, peritubular cells; ST, seminiferous tubules; TC, telocyte

rich structures from the ones equipped with scarce microfilaments and/or arranged in a different way (present in other testicular cell types) when using basic fluorescence microscopy. The same morphological features were described for TCs in other tissues (Nicolescu et al. 2012; Cretoiu et al. 2012;

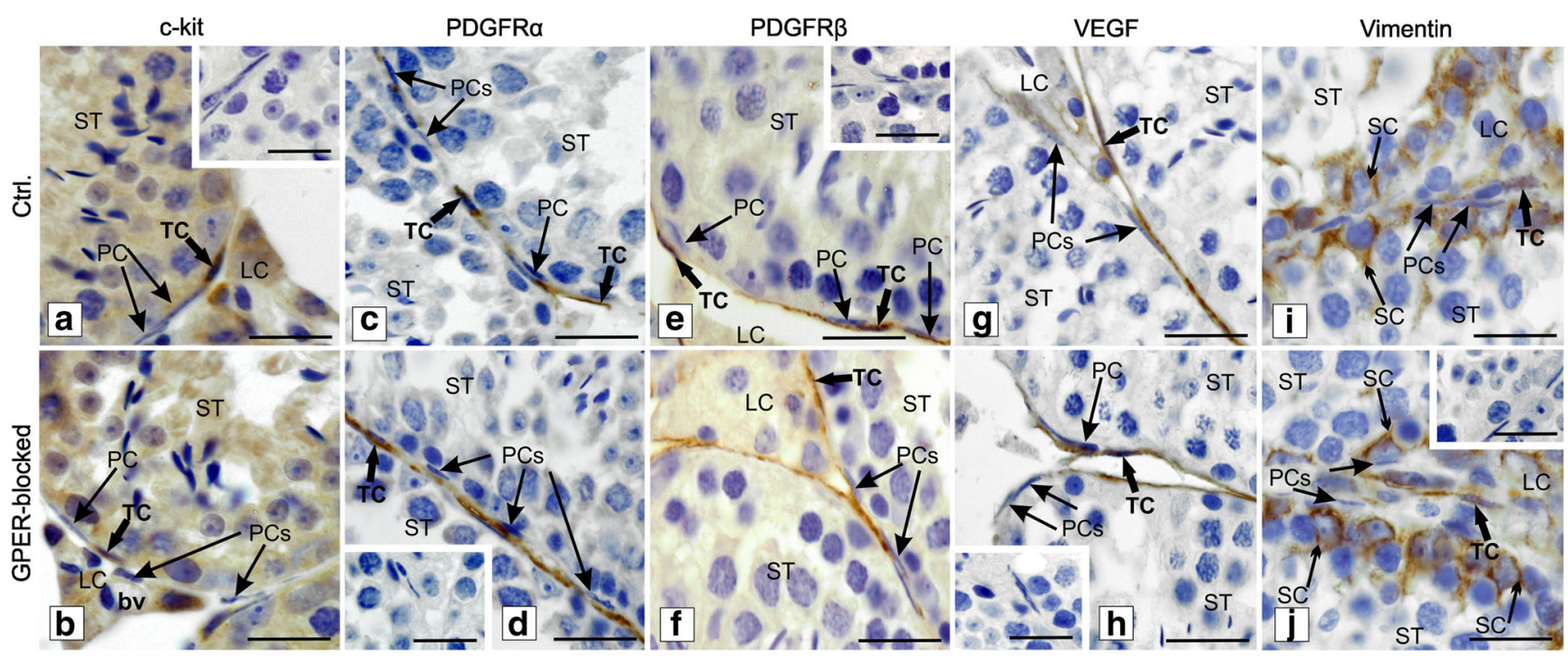

Fig. 4 Presence of telocytes in mouse testis-immunohistochemical analysis. Effect of GPER blockage. Representative microphotographs of c-kit, PDGFR $\alpha$ and $\beta$, VEGF, and vimentin immunohistochemical localization in control $(\mathbf{a}, \mathbf{c}, \mathbf{e}, \mathbf{g}, \mathbf{i})$ and GPER-blocked $(\mathbf{b}, \mathbf{d}, \mathbf{f}, \mathbf{h}, \mathbf{j})$ mouse testes. Immunostaining with $\mathrm{DAB}$ and counterstaining with hematoxylin. Scale bars represent $15 \mu \mathrm{m}$. Immunoreaction was performed on testicular serial sections from at least three animals of each experimental group. Inserts at $\mathbf{a}, \mathbf{d}, \mathbf{e}, \mathbf{h}$, and $\mathbf{j}-$ negative controls. bv, blood vessels; LC, Leydig cells; PC, peritubular cells; SC, Sertoli cells; ST, seminiferous tubules; TC, telocyte 

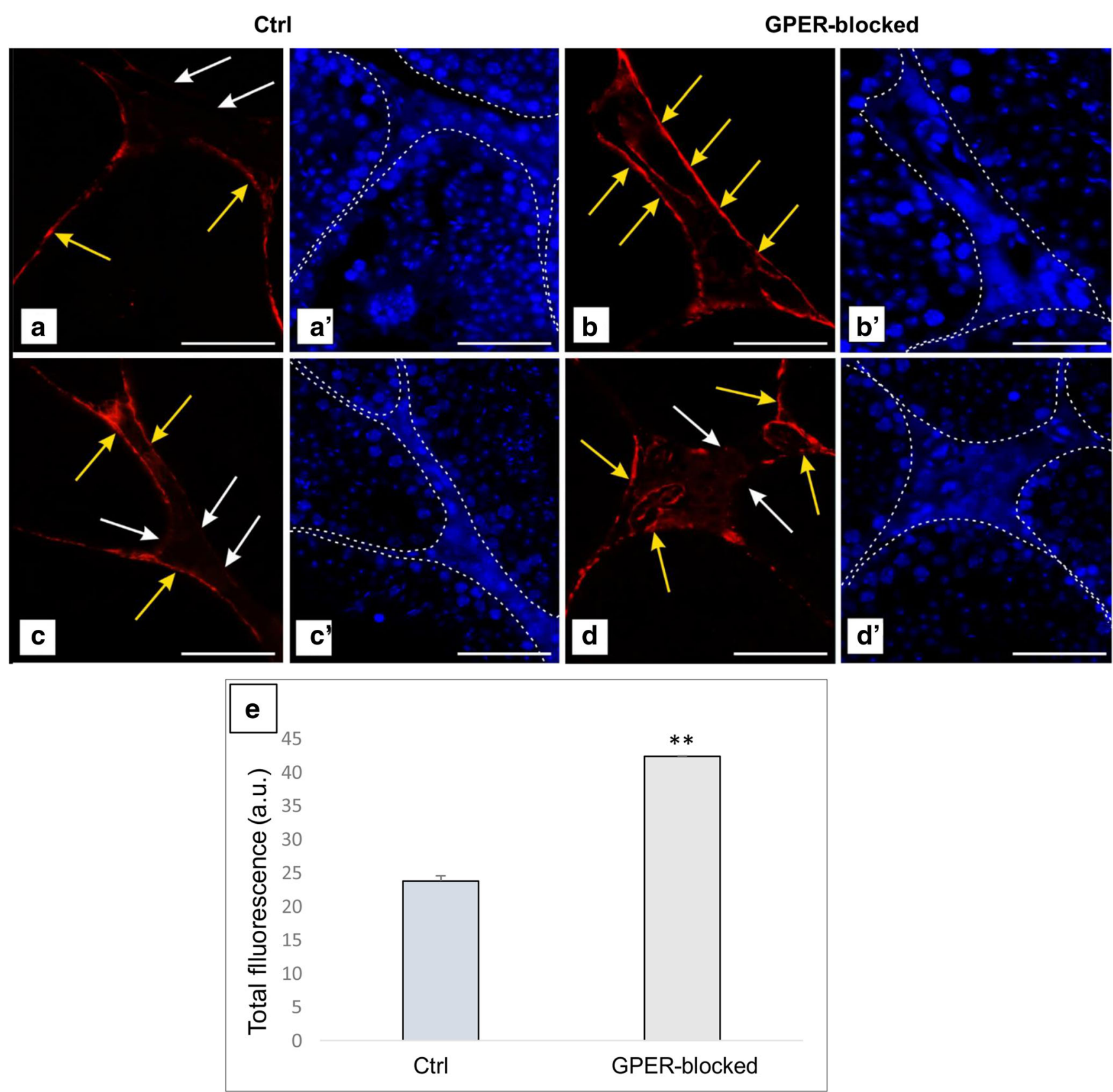

Fig. 5 Presence of telocytes in mouse testis-fluorescence analysis. Effect of GPER blockage. Representative microphotographs of F-actin distribution in control and GPER-blocked mouse testes (A, A', B, B', C, C ', D, D'). Fluorescence with DAPI. Scale bars represent $20 \mu \mathrm{m}$. Dashed lines mark the periphery of interstitial tissue. White arrows - positive stained telopodes; yellow arrows - places with lack of staining (lack of

Milia et al. 2013; Li et al. 2014; Rosa et al. 2018). In peritubular-myoid cells, abundant actin filaments are distributed in a species- and tissue-specific manner. In rats, the filaments within one peritubular cell run both longitudinally and circularly to the long axis of the seminiferous tubule, exhibiting a lattice-work pattern (Maekawa et al. 1996). In capillary cross sections, circumferential pericytes showed numerous parallel bundles of actin filaments forming a cap over
TCs and/or telopodes). Quantitative analysis of fluorescence (E). Histograms of fluorescent intensities expressed as relative fluorescence (arbitrary units; a.u.). Immunoreaction was performed on testicular serial sections from at least three animals of each experimental group. Data is expressed as means $\pm \mathrm{SD}$. Asterisks show significant differences between control and GPER-blocked testes. Values are denoted as ${ }^{* *} p<0.01$

the adjacent endothelial cells with a few actin filaments only (Wallow and Burnside 1980). Telocytes, peritubular cells, pericytes, and other cells of the interstitium may act in a coordinated manner to control contractility (via both cytoskeleton components including $\mathrm{F}$-actin microfilaments and mitochondrial energy) of the interstitium, seminiferous tubules, and vessels, as well as modulate properties of the interstitial microenvironment. 


\section{a}

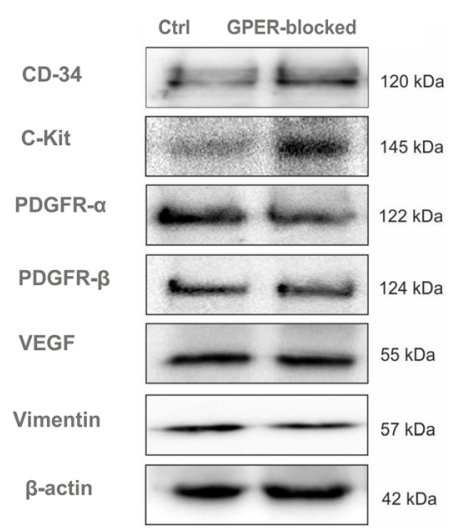

b
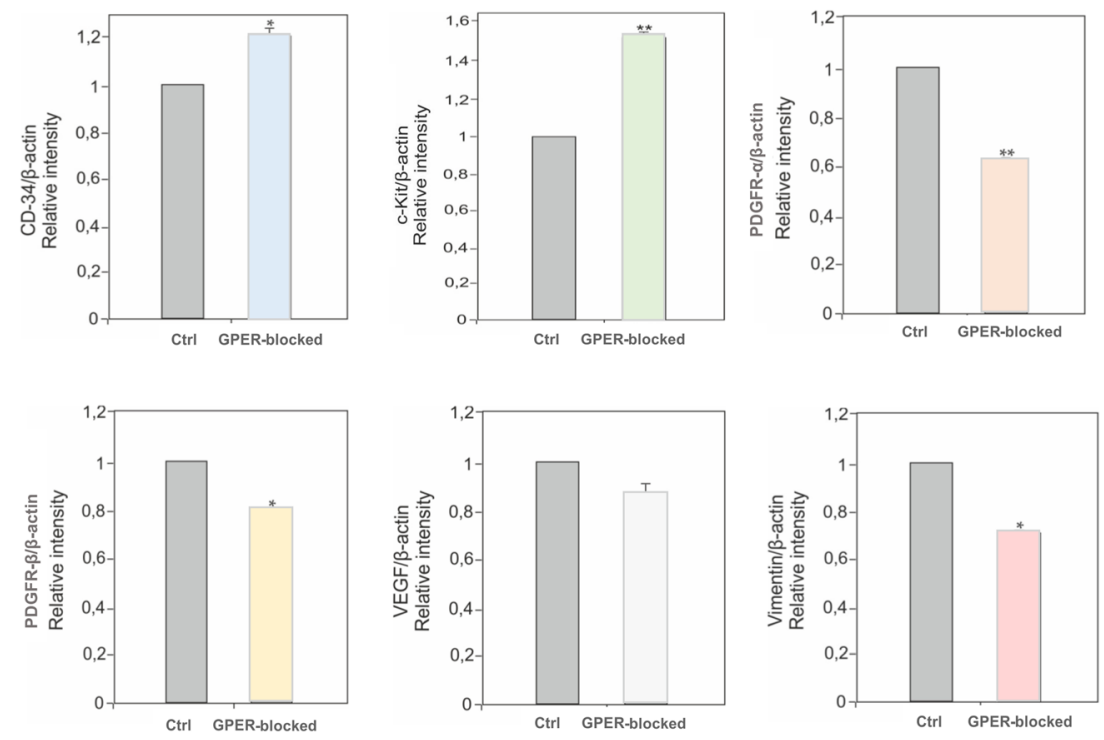

Fig. 6 Expression of CD34, c-kit, PDGFR $\alpha$, PDGFR $\beta$, VEGF, and vimentin in mouse testis. Effect of GPER blockage. Representative blots of qualitative expression (a) and relative expression (arbitrary units) (b) of proteins CD34, c-kit, PDGFR $\alpha$, PDGFR $\beta$, VEGF, and vimentin in control and GPER-blocked mouse testes. Protein densitometry results are present below the corresponding blots. The relative amount

As a second step, according to Popescu and FaussonePellegrini (2010) after electron microscopic TC identification, we tried to find the most suitable protein marker for identification of testicular TCs. Depending on tissue and species studied, diverse TC markers were identified through many years (Popescu and Faussone-Pellegrini 2010). From the mesenchymal cell markers commonly used for TC identification, e.g., CD34, c-kit, PDGFR $\alpha$ and $\beta$, VEGF, and vimentin, two of them c-kit and vimentin seem
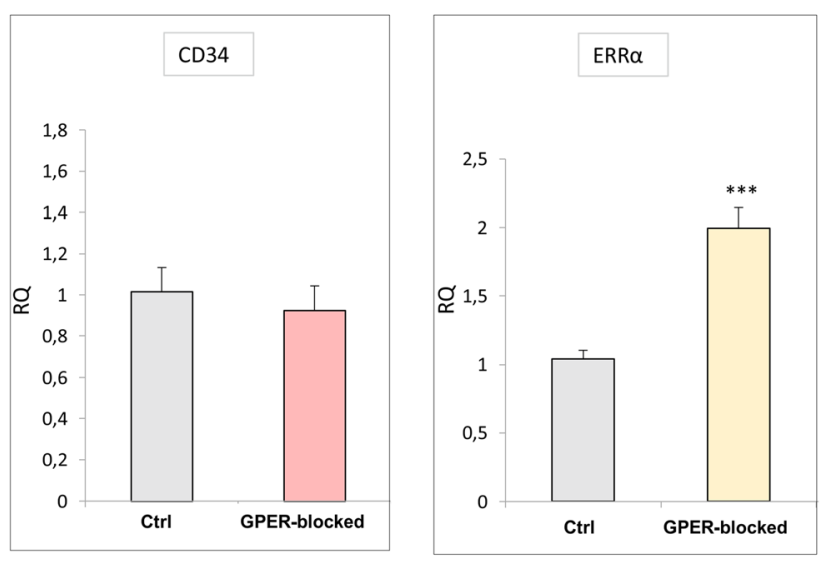

Fig. 7 Expression of CD34 and ERRs mRNA in mouse testis. Effect of GPER blockage. Relative level (relative quantification; RQ) of mRNA for $\mathrm{CD} 34, \mathrm{ERR} \alpha, \mathrm{ERR} \beta$, and ERR $\gamma$ in control and GPER-blocked mouse testes determined using real-time RT-PCR analysis $2^{-\Delta \Delta C t}$ method. As an intrinsic control, $\beta$-actin mRNA level was measured in the of respective proteins normalized to $\beta$-actin. ROD from three separate analyses is expressed as means. From each animal, at least three samples were measured. Asterisks show significant differences control and GPER-blocked testes. Data is expressed as means. Values are denoted as ${ }^{*} p<0.05$ and ${ }^{* *} p<0.01$

to be not suitable enough for distinguishing testicular TCs from other testicular mesenchymal cells, e.g., pericytes, fibroblasts as well as other types of testicular cells, e.g., Leydig cells, and macrophages (Feng et al. 1999; Fu et al. 2015; Zhou et al. 2015; Xiao et al. 2016). In addition, especially for c-kit, nonspecific staining occurred, too. On the other hand, CD34 seems to be the most relevant/helpful one; however, it is still not perfect when studying TCs in the testis.
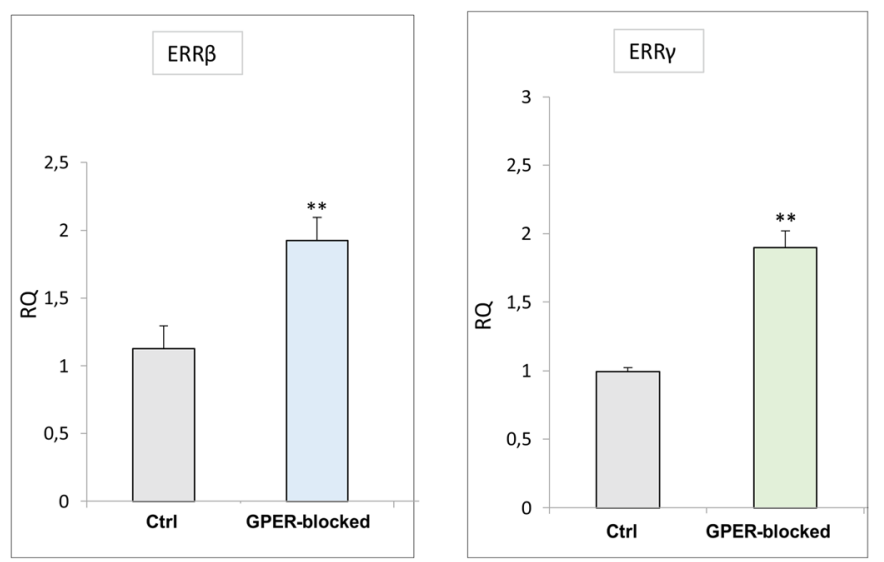

samples. From each animal, at least three samples were measured. RQ is expressed as means $\pm \mathrm{SD}$. Asterisks show significant differences between control and GPER-blocked testes. Values are denoted as ${ }^{* *} p<0.01$ and ${ }^{* * *} p<0.001$ 


\section{a}

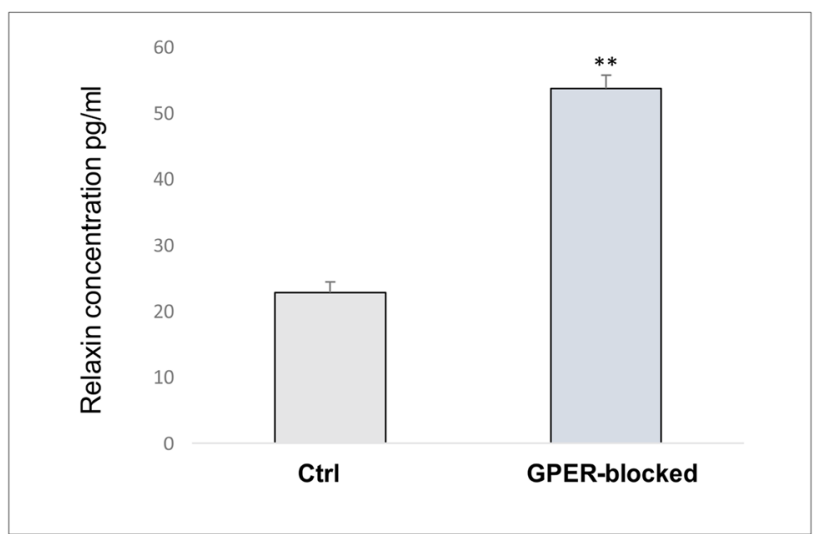

Fig. 8 Intratesticular relaxin and $\mathrm{Ca}^{2+}$ concentrations. Effect of GPER blockage. Relaxin (a) and $\mathrm{Ca}^{2+}$ (b) concentration in control and GPERblocked mouse testes. Data is expressed as means \pm SD. From each

Based on our results, changes in the expression of CD34, ckit, PDGFR $\alpha$ and $\beta$, VEGF, and vimentin showed that either TC number and protein expression or number and protein expression of other interstitial cells can be GPER-dependent. Of note, differences in the intensity of staining between individual protein analyzed by immunohistochemistry and Western blot can be related to different tissue preparations, e.g., fixation, blocking of nonspecific staining defined for each analyses, and thus, specific epitope antibody recognition. A significant increase in GPER expression in cells surrounding seminiferous tubules was found in men with mixed atrophy, although detailed description of cell type and number was not provided (Sandner et al. 2014). Also, increased TC number was reported by Hasirci et al. (2017) in the testis of men with maturation arrest and Sertoli cell-only syndrome. The authors also suggested that TCs act as pacemaker cells that serve to induce spermatogenesis. Similarly, TC content is crucial for the stimulation of prostate function (McHale et al. 2006). In contrast, in patients with testicular atrophy and fibrosis, the number of TCs was reduced due to deformation of the testicular tissue.

A series of studies have revealed that sex steroid imbalance, caused by either hormonal or nonhormonal endogenous and exogenous factors, is responsible for changes in quantity and function of testicular cells (Schanbacher et al. 1987; Abney and Myers 1991; Hejmej et al. 2005; Gould et al. 2007; Carreau and Hess 2010; Lucas et al. 2011; KotulaBalak et al. 2012; Rebourcet et al. 2014; Soliman and Emeish 2017). Moreover, in endocrine tissues, receptor number is controlled via hormone levels. Expression changes in one type of estrogen receptor affect the function of other estrogen receptors in various tissues and physiological conditions (Balasinor et al. 2010; Nephew et al. 2000; Kang et al. 2010; Madeira et al. 2013; Naugle et al. 2014; Boscia et al. 2015; Trejter et al. 2015; Kotula-Balak et al. 2018, b). In this
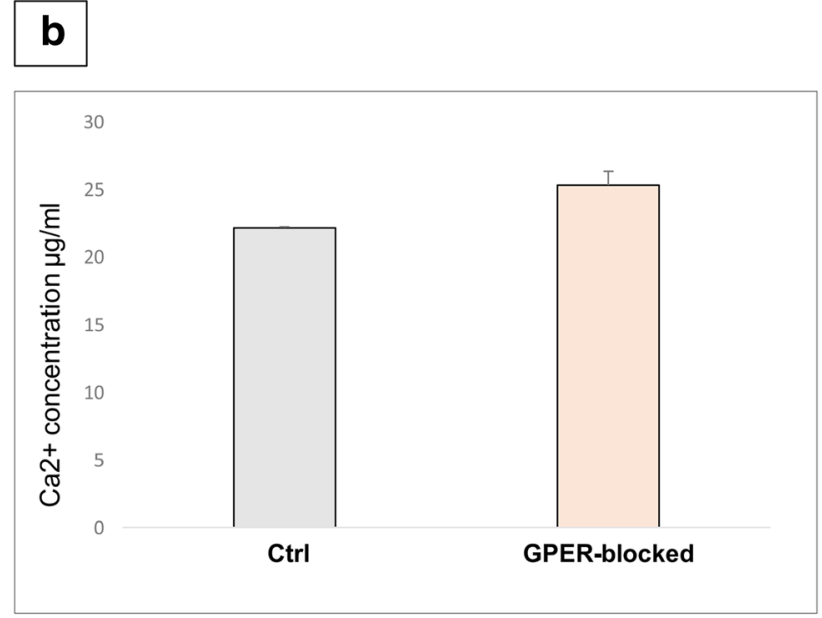

animal, at least three samples were measured. Asterisks show significant differences between control and GPER-blocked testes. Values are denoted as ${ }^{* *} p<0.01$

study, mRNA expression of CD34 varied along with that of ERR; however, their expression trended in opposite directions. This indicates the influence of TCs on the testis interstitium and/or reversely on TCs via GPER and ERR signaling. Transcription and translation can be differentially controlled as is reflected here for CD34 mRNA and protein expression. In addition, the half-life of protein can be increased while its degradation is reduced in GPER-blocked testes.

Based on our previous results, Leydig cell ultrastructure following GPER blockage was characterized by lipid droplets surrounded via concentrically in structure endoplasmic reticulum but also degenerating (combined with a lipophagy) lipid droplets (Kotula-Balak et al. 2018). In the present study, no changes in TC ultrastructure in the control and GPER-blocked testis were revealed. Such a result reflects the higher sensitivity of Leydig cells to changes in hormonal interstitium microenvironment than seen in TCs. Also, TC structure and undiscovered function was not based on high-energy metabolism when compared to Leydig cells. We found that the absence of GPER does not induce perturbation of TC function at the organelle level.

Alterations in estrogen signaling and cellular communication following GPER blockage, along with tendency to number changes, can lead to further histological alterations of the interstitial tissue, e.g., hypertrophy or fibrosis (Haines et al. 2012), for example, via TC functional alterations and/or effect of these alterations on functionality of other interstitial cells.

In GPER-blocked testis, increased relaxin concentrations, exclusively secreted by interstitial cells (e.g., Leydig cells), indicate potential tissue histological changes. Indeed, we have lastly demonstrated the association of estrogen, ERR, and relaxin in bank vole interstitium overgrowth (Pawlicki et al. 2017). Possible tissue remodeling, early malignant transformation, or fibrosis (due to alterations mainly in the function of fibroblasts) should not be excluded. The development of 
relaxin-null mice provided particularly strong evidence that relaxin functions to protect against fibrosis (Samuel et al. 2007; Bennett 2009). The role of canonical estrogen receptors and estradiol in the development of cardiac, renal, and systemic fibrosis was also evidenced (Pedram et al. 2010; Hewitson et al. 2012; Aida-Yasuoka et al. 2013). Notably, loss of TCs accompanies fibrosis of multiple organs in systemic sclerosis (Manetti et al. 2014). In Caucasians, cystic fibrosis is linked to infertility (Sokol 2001).

In GPER-blocked testis, modulation of estrogen signaling affected TC distribution, potentially TC number and probably TC function, reflecting changes in the tissue's histological appearance. In the light of these data, interaction of TCs, including possibly the secretory one, with estrogen and relaxin signaling supports TC involvement in interstitial tissue architecture and function. In addition, through TC release of inflammatory factors such as cytokines and interferons, their involvement in local immuno-inflammatory processes is feasible (Li et al. 2014; Ye et al. 2017).

According to $\mathrm{Fu}$ et al. (2015) and Ibba-Manneschi et al. (2016), enhancing the growth and/or survival of TCs could be an additional antifibrotic therapeutic strategy in many organs. Nowadays, in clinical andrology, treatment solutions for precocious gonad aging and tumorigenesis are intensively seeking (Giwercman and Giwercman 2011). Based on our results, GPER and ERR signaling modulation should be considered in future studies regarding the use of TCs against tissue pathological changes.

As mentioned above, TCs communicate via paracrine hormones but also via gap junctions that can be closed in response to high concentrations of $\mathrm{Ca}^{2+}$ (for review, see Calì et al. 2015). The heart rate is increased by relaxin modulation of the $\mathrm{Ca}^{2+}$ current in cardiac pacemaker cells (Han et al. 1994). In TCs of the female reproductive system, T-type $\mathrm{Ca}^{2+}$ channels contribute to the mechanical sensing of TCs, and what is more, estradiol controls its voltage gate (Banciu et al. 2018; Cretoiu et al. 2015). Interestingly, in isolated rat uterus, relaxin plays a double role as a transporter and buffer of $\mathrm{Ca}^{2+}$ (Fields 2005). For contraction of the rat testicular capsule, $\mathrm{Ca}^{2+}$ is needed (da Silva Júnior et al. 2013). Hence, $\mathrm{Ca}^{2+}$, together with relaxin, of which the contractile properties are well-known, is an important player controlling the interstitium tonus and creating the interstitial microenvironment. Our studies revealed no marked changes in $\mathrm{Ca}^{2+}$ level in GPER-blocked testis; thus, GPER is not directly implicated in $\mathrm{Ca}^{2+}$ regulation and it is possible that testicular TCs are not directly implicated in $\mathrm{Ca}^{2+}$ signaling. Future studies are warranted to elucidate the potential role of lipid droplets in TCs and their lipid homeostasis regulation apparently not by $\mathrm{Ca}^{2+}$.

Based on our current observations (direct lines of evidence from electron microscopic studies and indirect from immuohistochemical studies), we report, for the first time, the presence of TCs in mouse testis together with practical information regarding the analysis of TCs in electron microscopy and light microscopy (via protein markers) that can be useful for identification of testicular TCs. We hypothesize TC implication through tendency in their number changes in contractile and secretory function and/or their regulation of other interstitial cells in estrogen microenvironment including GPER-ERR interaction. Further studies in order to develop specific methods for TC identification and isolation and studies of their molecular characteristics and role in the testis are needed.

Acknowledgements The authors are very grateful to the editor and anonymous reviewers for their constructive suggestion and helpful comments that helped improve this manuscript.

The Hitachi S-4700 scanning electron microscope (Hitachi, Tokyo, Japan) was available in the Institute of Geological Sciences, Jagiellonian University in Krakow. The Jeol JEM 2100 transmission electron microscope was available at the Laboratory of Microscopy, Department of Cell Biology and Imaging, Institute of Zoology and Biomedical Research, Jagiellonian University in Krakow.

Author contributions Authors' contribution to the work described in the paper: P.P., A.H., W.T., K.L., BJ. P., A.M., E.G-W., B. P., A.H., M. K-B performed research. P.P., A.H., W.T., BJ. P., B.P., M. K-B, B.B. analyzed the data. B.B. critically reviewed the manuscript. M.K.-B. designed the research study and wrote the paper. All authors have read and approved the final version of the manuscript.

Funding This work was supported by grants SONATA BIS5 2015/18/E/ NZ4/00519 (M.K-B) and OPUS12 2016/23/B/NZ4/01788 (M.K-B) from the National Science Centre, Poland.

\section{Compliance with ethical standards}

All applicable international, national, and/or institutional guidelines for the care and use of animals were followed.

Conflict of interest The authors declare that they have no conflict of interest.

Open Access This article is distributed under the terms of the Creative Commons Attribution 4.0 International License (http:// creativecommons.org/licenses/by/4.0/), which permits unrestricted use, distribution, and reproduction in any medium, provided you give appropriate credit to the original author(s) and the source, provide a link to the Creative Commons license, and indicate if changes were made.

\section{References}

Abney TO, Myers RB (1991) 17 Beta-estradiol inhibition of Leydig cell regeneration in the ethane dimethylsulfonate-treated mature rat. $\mathrm{J}$ Androl 12(5):295-304

Aida-Yasuoka K, Peoples C, Yasuoka H, Hershberger P, Thiel K, Cauley JA, Medsger TA Jr, Feghali-Bostwick CA (2013) Estradiol promotes the development of a fibrotic phenotype and is increased in the serum of patients with systemic sclerosis. Arthritis Res Therapy 15:R10

Balasinor NH, D'Souza R, Nanaware P, Idicula-Thomas S, KediaMokashi N, He Z, Dym M (2010) Effect of high intratesticular 
estrogen on global gene expression and testicular cell number in rats. Reprod Biol Endocrinol 23(8):72

Banciu M, Banciu DD, Mustaciosu CC, Radu M, Cretoiu D, Xiao J, Cretoiu SM, Suciu M, Radu BM (2018) Beta-estradiol regulates voltage-gated calcium channels and estrogen receptors in telocytes from human myometrium. Int J Mol Sci 19(5):E1413

Bennett RG (2009) Relaxin and its role in the development and treatment of fibrosis. Tansl Res 154(1):1-6

Bjornstrom L, Sjoberg M (2005) Mechanisms of estrogen receptor signaling: convergence of genomic and nongenomic actions on target genes. Mol Endocrinol 19:833-842

Boscia F, Passaro C, Gigantino V, Perdonà S, Franco R, Portella G, Chieffi S, Chieffi P (2015) High levels of GPR30 protein in human testicular carcinoma in situ and seminomas correlate with low levels of estrogen receptor-beta and indicate a switch in estrogen responsiveness. J Cell Physiol 230(6):1290-1297

Calì B, Ceolin S, Ceriani F, Bortolozzi M, Agnellini AH, Zorzi V, Predonzani A, Bronte V, Molon B, Mammano F (2015) Critical role of gap junction communication, calcium and nitric oxide signaling in bystander responses to focal photodynamic injury. Oncotarget 6(12):10161-10174

Carreau S, Hess RA (2010) Oestrogens and spermatogenesis. Philos Trans R Soc Lond Ser B Biol Sci 365(1546):1517-1535

Chimento A, Sirianni R, Casaburi I, Pezzi V (2014) GPER signaling in spermatogenesis and testicular tumors. Front Endocrinol (Lausanne) 6(5):30

Christensen AK (1975) Leydig cells. In: Greep RO, Aswood EB (eds) Handbook of physiology. section 7, vol 5. American Physiological Society, Washington, DC, pp 57-94

Cretoiu SM, Cretoiu D, Popescu LM (2012) Human myometrium - the ultrastructural 3D network of telocytes. J Cell Mol Med 16:2844 2849

Cretoiu SM, Popescu LM (2014) Telocytes revisited. Biomol Concepts 5(5):353-369

Cretoiu SM, Radu BM, Banciu A, Banciu DD, Cretoiu D, Ceafalan LC, Popescu LM (2015) Isolated human uterine telocytes: immunocytochemistry and electrophysiology of T-type calcium channels. Histochem Cell Biol 143(1):83-94

da Silva Júnior ED, de Souza BP, Rodrigues JQ, Caricati-Neto A, Jurkiewicz A, Jurkiewicz NH (2013) Functional characterization of acetylcholine receptors and calcium signaling in rat testicular capsule contraction. Eur J Pharmacol 714(1-3):405-413

Díaz-Flores L, Gutiérrez R, Díaz-Flores L Jr, Goméz MG, Sáez FJ, Madrid JF (2016) Behaviour of telocytes during physiopathological activation. Semin Cell Dev Biol 55:50-61

Feng HL, Sandlow JI, Sparks AE, Sandra A, Zheng LJ (1999) Decreased expression of the c-kit receptor is associated with increased apoptosis in subfertile human testes. Fertil Steril 71(1):85-89

Fields PA (2005) Is relaxin a calcium transporter/buffer? Ann N Y Acad Sci 1041:328-331

Fu S, Wang F, Cao Y, Huang Q, Xiao J, Yang C, Popescu LM (2015) Telocytes in human liver fibrosis. J Cell Mol Med 19(3):676-683

Giwercman A, Giwercman YL (2011) Environmental factors and testicular function. Best Pract Res Clin Endocrinol Metab 25(2):391-402

Gould ML, Hurst PR, Nicholson HD (2007) The effects of oestrogen receptors alpha and beta on testicular cell number and steroidogenesis in mice. Reproduction 134(2):271-279

Haines CD, Harvey PA, Leinwand LA (2012) Estrogens mediate cardiac hypertrophy in a stimulus-dependent manner. Endocrinology 153(9):4480-4490

Han X, Habuchi Y, Giles WR (1994) Relaxin increases heart rate by modulating calcium current in cardiac pacemaker cells. Circ Res 74(3):537-541

Hasirci E, Turunc T, Bal N, Goren MR, Celik H, Kervancioglu E, Dirim A, Tekindal MA, Ozkardes H (2017) Distribution and number of
Cajal-like cells in testis tissue with azoospermia. Kaohsiung J Med Sci 33(4):181-186

Hejmej A, Gorazd M, Kosiniak-Kamysz K, Wiszniewska B, Sadowska J, Bilińska B (2005) Expression of aromatase and oestrogen receptors in reproductive tissues of the stallion and a single cryptorchid visualised by means of immunohistochemistry. Domest Anim Endocrinol 29(3):534-547

Hess RA (2003) Estrogen in the adult male reproductive tract: a review. Reprod Biol Endocrinol 1:52

Hewitson TD, Zhao C, Wigg B, Lee SW, Simpson ER, Boon WC, Samuel CS (2012) Relaxin and castration in male mice protect from, but testosterone exacerbates, age-related cardiac and renal fibrosis, whereas estrogens are an independent determinant of organ size. Endocrinology 153(1):188-199

Hinescu ME, Gherghiceanu M, Suciu L, Popescu LM (2011) Telocytes in pleura: two- and three-dimensional imaging by transmission electron microscopy. Cell Tissue Res 343:389-397

Huppunen J, Aarnisalo P (2004) Dimerization modulates the activity of theorphan nuclear receptor ERR. Biochem Biophys Res Commun 314:964-970

Ibba-Manneschi L, Rosa I, Manetti M (2016) Telocytes in chronic inflammatory and fibrotic diseases. Adv Exp Med Biol 913:51-76

Kang L, Zhang X, Xie Y, Tu Y, Wang D, Liu Z, Wang ZY (2010) Involvement of estrogen receptor variant ER-alpha36, not GPR30, in nongenomic estrogen signaling. Mol Endocrinol 24(4):709-721

Kotula-Balak M, Chojnacka K, Hejmej A, Galas J, Satola M, Bilinska B (2013) Does 4-tert-octylphenol affect estrogen signaling pathways in bank vole Leydig cells and tumor mouse Leydig cells in vitro? Reprod Toxicol 39: 6-16

Kotula-Balak M, Hejmej A, Kopera I, Lydka M, Bilinska B (2012) Prenatal and neonatal exposure to flutamide affects function of Leydig cells in adult boar. Domest Anim Endocrinol 42(3):142-154

Kotula-Balak M, Milon A, Pawlicki P, Opydo-Chanek M, Pacwa A, Lesniak K, Sekula M, Zarzycka M, Bubka M, Tworzydlo W, Bilinska B, Anna Hejmej A (2018) Insights into the role of estrogen-related receptors $\alpha, \beta$ and $\gamma$ in tumor Leydig cells. Tissue Cell 52:78-91

Kotula-Balak M, Pawlicki P, Milon A, Tworzydlo W, Sekula M, Pacwa A, Gorowska-Wojtowicz E, Bilinska B, Pawlicka B, Wiater J, Zarzycka M, Galas J (2018) The role of G-protein coupled membrane estrogen receptor in mouse Leydig cell function - in vivo and in vitro evaluation. Tissue Cell Res. https://doi.org/10.1007/s00441$018-2861-7$

Li L, Lin M, Li L, Wang R, Zhang C, Qi G, Xu M, Rong R, Zhu T (2014) Renal telocytes contribute to the repair of ischemically injured renal tubules. J Cell Mol Med 18(6):1144-1156

Li H, Lu S, Liu H, Ge J, Zhang H (2014) Scanning electron microscope evidence of telocytes in vasculature. J Cell Mol Med 18(7):14861489

Livak KJ, Schmittgen TD (2001) Analysis of relative gene expression data using real-time quantitative PCR and the 2(-Delta Delta C(T)) method. Methods 25:402-408

Lowry OH, Rosebrough NJ, Farr AL, Randall RJ (1951) Protein measurement with the Folin phenol reagent. J Biol Chem 193:265-275

Lucas TF, Pimenta MT, Pisolato R, Lazari MF, Porto CS (2011) 17Betaestradiol signaling and regulation of Sertoli cell function. Spermatogenesis 1(4):318-2410

Madeira M, Mattar A, Logullo AF, Soares FA, Gebrim LH (2013) Estrogen receptor alpha/beta ratio and estrogen receptor beta as predictors of endocrine therapy responsiveness - a randomized neoadjuvant trial comparison between anastrozole and tamoxifen for the treatment of postmenopausal breast cancer. BMC Cancer 18(13):425

Maekawa M, Kamimura K, Nagano T (1996) Peritubular myoid cells in the testis: their structure and function. Arch Histol Cytol 59(1):1-13 
Manetti M, Rosa I, Messerini L, Guiducci S, Matucci-Cerinic M, IbbaManneschi L (2014) A loss of telocytes accompanies fibrosis of multiple organs in systemic sclerosis. J Cell Mol Med 18(2):253-262

McDonald K (1984) Osmium ferricyanide fixation improves microfilament preservation and membrane visualization in a variety of animal cell types. J Ultrastruct Res 86(2):107-118

McHale N, Hollywood M, Sergeant G, Thornbury K (2006) Origin of spontaneous rhythmicity in smooth muscle. J Physiol 570:23-28

Michaylova V, Ilkova P (1971) Photometric determination of micro amounts of calcium with arsenazo III. Anal Chim Acta 53(1):194-198

Milia AF, Ruffo M, Manetti M, Rosa I, Conte D, Fazi M, Messerini L, Ibba-Manneschi L (2013) Telocytes in Crohn's disease. J Cell Mol Med 17(12):1525-1536

Milon A, Opydo-Chanek M, Tworzydlo W, Galas J, Pardyak L, Kaminska A, Ptak A, Kotula-Balak M (2017) Chlorinated biphenyls effect on estrogen-related receptor expression, steroid secretion, mitochondria ultrastructure but not on mitochondrial membrane potential in Leydig cells. Cell Tissue Res 369:429-444. https://doi.org/10. 1007/s00441-017-2596-x

Mokhtar DM, Abd-Elhafeez HH, Abou-Elmagd A, Hassan AH (2016) Melatonin administration induced reactivation in the seminal gland of the soay rams during nonbreeding season: an ultrastructural and morphometrical study. J Morphol 277:231-243

Mostafa RM, Moustafa YM, Hamdy H (2010) Interstitial cells of Cajal, the Maestro in health and disease. World J Gastroenterol 16(26): 3239-3248

Naugle MM, Nguyen LT, Merceron TK, Filardo E, Janssen WG, Morrison JH, Rapp PR, Gore AC (2014) G-protein coupled estrogen receptor, estrogen receptor $\alpha$, and progesterone receptor immunohistochemistry in the hypothalamus of aging female rhesus macaques given long-term estradiol treatment. J Exp Zool A Ecol Genet Physiol 321(7):399-414

Nephew KP, Long X, Osborne E, Burke KA, Ahluwalia A, Bigsby RM (2000) Effect of estradiol on estrogen receptor expression in rat uterine cell types. Biol Reprod 62(1):168-177

Nicolescu MI, Bucur A, Dinca O, Rusu MC, Popescu LM (2012) Telocytes in parotid glands. Anat Rec (Hoboken) 295(3):378-385

Pardyak L, Kaminska A, Galas J, Ptak A, Bilinska B, Kotula-Balak M (2016) Primary and tumor mouse Leydig cells exposed to polychlorinated naphthalenes mixture: effect on estrogen relatedreceptors expression, intracellular calcium level and sex hormones secretion. Tissue Cell 48(5):432-441

Park E, Kumar S, Lee B, Kim KJ, Seo JE, Choi HS, Lee K (2017) Estrogen receptor-related receptor $\gamma$ regulates testicular steroidogenesis through direct and indirect regulation of steroidogenic gene expression. Mol Cell Endocrinol 452:15-24

Pawlicki P, Milon A, Zarzycka M, Galas J, Tworzydlo W, Kaminska A, Pardyak L, Lesniak K, Pacwa A, Bilinska B, Gorowska-Wojtowicz E, Kotula-Balak M (2017) Does signaling of estrogen-related receptors affect structure and function of bank vole Leydig cells? J Physiol Pharmacol 68(3):459-476

Pedram A, Razandi M, O'Mahony F, Lubahn D, Levin ER (2010) Estrogen receptor-beta prevents cardiac fibrosis. Mol Endocrinol 24(11):2152-2165

Pfaffl MW (2001) A new mathematical model for relative quantification in real-time RT-PCR. Nucleic Acids Res 29: p. e45

Popescu LM (2011) The tandem: telocytes-stem cells. Int J Biol Biomed Eng 5:83-92

Popescu LM, Ciontea SM, Cretoiu D, Hinescu ME, Radu E, Ionescu N, Ceausu M, Gherghiceanu M, Braga RI, Vasilescu F, Zagrean L, Ardeleanu C (2005) Novel type of interstitial cell (Cajal-like) in human fallopian tube. J Cell Mol Med 9(2):479-523

Popescu LM, Curici A, Wang E, Zhang H, Hu S, Gherghiceanu M (2015) Telocytes and putative stem cells in ageing human heart. J Cell Mol Med 19:31-45
Popescu LM, Faussone-Pellegrini MS (2010) Telocytes - a case of serendipity: the winding way from interstitial cells of Cajal (ICC), via interstitial Cajal-like cells (ICLC) to telocytes. J Cell Mol Med 14: $729-740$

Popescu LM, Manole CG, Gherghiceanu M, Ardelean A, Nicolescu MI, Hinescu ME, Kostin S (2010) Telocytes in human epicardium. J Cell Mol Med 14:2085-2093

Radu BM, Banciu A, Banciu DD, Radu M, Cretoiu D, Cretoiu SM (2017) Calcium signaling in interstitial cells: focus on telocytes. Int J Mol Sci 13(18):2

Rebourcet D, O'Shaughnessy PJ, Monteiro A, Milne L, Cruickshanks L, Jeffrey N, Guillou F, Freeman TC, Mitchell RT, Smith LB (2014) Sertoli cells maintain Leydig cell number and peritubular myoid cell activity in the adult mouse testis. PLoS One 9:8-e105687

Roatesi I, Radu BM, Cretoiu D, Cretoiu SM (2015) Uterine telocytes: a review of current knowledge. Biol Reprod 93:10

Rodríguez H, Espinoza-Navarro O, Sarabia L, Tamayo C, Sepúlveda M, Inostroza J, Araya JC, Moriguchi K (2008) Histological and functional organization in human testicle: expression of receptors c-kit and androgens. Int J Morphol 26(3):603-608

Rosa I, Marini M, Guasti D, Ibba-Manneschi L, Manetti M (2018) Morphological evidence of telocytes in human synovium. Sci Rep 8(1):3581

Roshan-Moniri M, Hsing M, Butler MS, Cherkasov A, Rennie PS (2014) Orphan nuclear receptor $\mathrm{s}$ as drug targets for the treatment of prostate and breast cancers. Cancer Treat Rev 40:1137-1152

Russell LD, Burguet S (1977) Ultrastructure of Leydig cells as revealed by secondary tissue treatment with a ferrocyanide-osmium mixture. Tissue Cell 9:751-766

Samuel CS, Lekgabe ED, Mookerjee I (2007) The effects of relaxin on extracellular matrix remodeling in health and fibrotic disease. Adv Exp Med Biol 612:88-103

Sanches BDA, Maldarine JS, Zani BC, Tamarindo GH, Biancardi MF, Santos FCA, Rahal P, Góes RM, Felisbino SL, Vilamaior PSL, Taboga SR (2017) Telocytes play a key role in prostate tissue organisation during the gland morphogenesis. J Cell Mol Med 21(12): $3309-3321$

Sanders KM, Ward SM, Koh SD (2014) Interstitial cells: regulators of smooth muscle function. Physiol Rev 94(3):859-907

Sandner F, Welter H, Schwarzer JU, Köhn FM, Urbanski HF, Mayerhofer A (2014) Expression of the estrogen receptor GPER by testicular peritubular cells is linked to sexual maturation and male fertility. Andrology 2(5):695-701

Schanbacher BD, Fletcher PW, Reichert LE Jr (1987) Testicular compensatory hypertrophy in the hemicastrated calf: effects of exogenous estradiol. Biol Reprod 36(5):1142-1148

Sharpe RM, Walker M, Millar MR, Atanassova N, Morris K, McKinnell C, Saunders PT, Fraser HM (2000) Effect of neonatal gonadotropinreleasing hormone antagonist administration on Sertoli cell number and testicular development in the marmoset: comparison with the rat. Biol Reprod 62:1685-1693

Skinner MK, Norton JN, Mullaney BP, Rosselli M, Whaley PD, Anthony CT (1991) Cell-cell interactions and the regulation of testis function. Ann N Y Acad Sci 637:354-363

Smolen AJ (1990) Image analytic techniques for quantification of immunocytochemical staining in the nervous system. In: Conn PM (ed) Methods in neurosciences. Academic, San Diego, pp 208-229

Sokol RZ (2001) Infertility in men with cystic fibrosis. Curr Opin Pulm Med 7(6):421-426

Soliman A, Emeish W (2017) Morphological alternations of intraepithelial and stromal telocytes in response to salinity challenges. bioRxiv. https://doi.org/10.1101/115881

Trejter M, Jopek K, Celichowski P, Tyczewska M, Malendowicz LK, Rucinski M (2015) Expression of estrogen, estrogen related and androgen receptors in adrenal cortex of intact adult male and female rats. Folia Histochem Cytobiol 53(2):133-144 
Vanacker JM, Pettersson K, Gustafsson JA, Laudet V (1999) Transcriptionaltargets shared by estrogen receptor-related receptors (ERRs) and estrogenreceptor (ER) alpha but not by ERbeta. EMBO J 18:4270-4279

Vaucher L, Funaro MG, Mehta A, Mielnik A, Bolyakov A, Prossnitz ER, Schlegel PN, Paduch DA (2014) Activation of GPER-1 estradiol receptor downregulates production of testosterone in isolated rat Leydig cells and adult human testis. PLoS One 9(4):e92425

Vögler O, Barceló JM, Ribas C, Escribá PV (2008) Membrane interactions of $\mathrm{G}$ proteins and other related proteins. Biochim Biophys Acta 1778(7-8):1640-1652

Vrtačnik P, Ostanek B, Mencej-Bedrač S, Marc J (2014) The many faces of estrogen signaling. Biochem Med (Zagreb) 24(3):329-342

Wallow IH, Burnside B (1980) Actin filaments in retinal pericytes and endothelial cells. Invest Ophthalmol Vis Sci 19(12):1433-1441

Wang F, Song Y, Bei Y, Zhao Y, Xiao J, Yang C (2014) Telocytes in liver regeneration: possible roles. J Cell Mol Med 18:1720-1726

Xiao J, Chen P, Qu Y, Yu P, Yao J, Wang H, Fu S, Bei Y, Chen Y, Che L, $\mathrm{Xu} J$ (2016) Telocytes in exercise-induced cardiac growth. J Cell Mol Med 20(5):973-979
Yamashita M (2010) Synchronization of $\mathrm{Ca} 2+$ oscillations: a capacitative (AC) electrical coupling model in neuroepithelium. FEBS J 277: 293-299

Yang P, Ahmad N, Hunag Y, Ullah S, Zhang Q, Waqas Y, Liu Y, Li Q, Hu L, Chen Q (2015) Telocytes: novel interstitial cells present in the testis parenchyma of the Chinese soft-shelled turtle Pelodiscus sinensis. J Cell Mol Med 19(12):2888-2899

Yang Y, Sun W, Wu SM, Xiao J, Kong X (2014) Telocytes in human heart valves. J Cell Mol Med 18:759-765

Ye L, Song D, Jin M, Wang X (2017) Therapeutic roles of telocytes in OVA-induced acute asthma in mice. J Cell Mol Med 21(11):28632871

Zarzycka M, Gorowska-Wojtowicz E, Tworzydlo W, Klak A, Kozub K, Hejmej A, Bilinska B, Kotula-Balak M (2016) Are aryl hydrocarbon receptor and G-protein-coupled receptor 30 involved in the regulation of seasonal testis activity in photosensitive rodent-the bank vole (Myodes glareolus)? Theriogenology 86(3):674-686

Zhou Q, Wei L, Zhong C, Fu S, Bei Y, Huică RI, Wang F, Xiao J (2015) Cardiac telocytes are double positive for CD34/PDGFR- $\alpha$. J Cell Mol Med 19(8):2036-2204 